\title{
PELATIHAN DAN PENDAMPINGAN PENGOLAHAN PASCA PANEN UMBI GARUT PADA KELOMPOK TANI PELANGI DI DESA KASENGAN KABUPATEN SUMENEP
}

\author{
R. Amilia Destryana ${ }^{1)}$, Aryo Wibisono ${ }^{2)}$, Eko Adi Sumitro' ${ }^{1)}$ \\ ${ }^{1}$ Teknologi Hasil Pertanian, Fakultas Pertanian, Universitas Wiraraja \\ ${ }^{2}$ Fakultas Ekonomi dan Bisnis, Universitas Wiraraja
}

\begin{abstract}
Abstrak
Umbi garut sudah dikenal luas oleh masyarakat, sebagai bahan pangan lokal dijadikan sebagai bahan pangan alternatif maupun penghasil pati untuk bahan baku industri pengolahan pangan. Prospek umbi garut sebagai penghasil pati (tepung) adalah sebagai substitusi tepung gandum. Desa Kasean merupakan daerah di Kecamatan Manding yang berpotensi sebagai penghasil garut di Kecamatan Sumenep. Melalui kegiatan pemberdayaan atau pengabdian kepada masyarakat utamanya Kelompok Tani Pelangi di Desa Kasengan, Kecamatan Manding untuk menciptakan kondisi kemandirian pangan sekaligus menjaga ketahanan pangan lokal serta memperbaiki mekanisme perekonomian rakyat. Metode penyelesaian masalah yang dapat dilakukan yaitu 1) mendampingi petani dan memotivasi untuk lebih menghargai umbi garut sebagai bahan pangan alternatif dan 2) meningkatkan nilai ekonomis tanaman Garut dengan penanganan pasca panen yang baik. Hasil dari kegiatan PKM ini adalaha adanya respon positif dari kelompok dalam bentuk keaktifan dan peningkatan keterampilan kelompok tani Pelangi terkait penanganan lepas panen umbi garut, spesifik pada pengolahan umbi garut (tepung) menjadi berbagai produk olahan pangan. Selain itu, mitra PKM dapat mengaplikasikan proses pengolahan produk olahan pati garut. Rekomendasi untuk kegiatan pengabdian kepada masyarakat berikutnya adalah pemanfaatan komoditas lokal lainnya di Desa Kasengan yang berpotensi dalam produksi olahan pangan fungsional. Selain itu, perlunya jejaring pemasaran yang lebih luas daripada pasar lokal.
\end{abstract}

Kata Kunci: umbi garut, pati garut, pendampingan, kelompok tani, desa Kasengan.

\begin{abstract}
Garut tubers are widely known by the community, as local food is used as alternative foodstuffs and starch producers for food processing industry raw materials. The prospect of arrowroot tubers as a producer of starch (flour) is as a substitute for wheat flour. Kasean Village is an area in Manding District which has the potential to produce arrowroot in Sumenep District. Through community empowerment or community service activities, especially the Pelangi Farmer Group in Kasengan Village, Manding District to create conditions for food independence while maintaining local food security and improving the people's economic mechanism. The problem solving methods that can be done are 1) accompanying farmers and motivating to better appreciate the arrowroot tubers as alternative food ingredients and 2) increasing the economic value of Garut plants by handling postharvest well. The result of this PKM activity is a positive response from the group in the form of activeness and improvement of the skills of the Pelangi farmer group related to handling the harvest off arrowroot tubers, specifically on the processing of arrowroot tubers (flour) into various processed food products. In addition, PKM partners can apply the processing of arrowroot starch processed products. The next recommendation for community service is the use of other local commodities in Kasengan Village that have the potential to produce functional food preparations. In addition, the need for a wider marketing network than the local market.
\end{abstract}

Keywords: arrowroot tuber, arrowroot starch, assistance, farmer groups, Kasengan village.

Correspondence author: R. Amilia Destryana, amiliadestryana@gmail.com, Sumenep, Indonesia 


\section{PENDAHULUAN}

Salah satu tujuan pembangunan pertanian secara nasional adalah ketahanan pangan. Secara umum tanaman garut sudah dikenal luas oleh masyarakat, sebagai bahan pangan lokal garut dijadikan sebagai bahan pangan alternatif maupun penghasil pati untuk bahan baku industri pengolahan pangan, yaitu pati dan emping garut. Prospek umbi garut sebagai penghasil pati (tepung) adalah sebagai substitusi tepung gandum, seperti dalam penggunaan bahan baku mie, kue, roti kering atau bahan pangan diet pengganti nasi, hal ini dikarenakan karakteristik keduanya hampir sama. Hal ini sejalan dengan arah dan sasaran kebijakan pembangunan pangan dan gizi, yaitu dalam mewujudkan ketahanan pangan, sehingga tidak bertumpu pada komoditas padi dan jagung.

Berbagai macam bahan pangan lokal yang berpotensi sebagai sumber pangan alternatif ditemukan di Indonesia, bahan pangan ini yang perlu dikembangkan untuk dapat mendukung kemandirian pangan. Tanaman umbi garut memiliki budidaya yang mudah dan umur panen selama 6-10 bulan, dapat dimanfaatkan sebagai pakan ternak dalam bentuk kering (limbah) (Djaafar \& Pustika, 2016). Manfaat dari umbi garut diantaranya sebagai sumber serat pangan dan memiliki indeks glikemik yang rendah jika dibandingkan dengan umbi-umbian lainnya (Hasan, Astuti, \& Susilawati, 2012).

Suatu bahan pangan alternatif seperti umbi-umbian dapat diusahakan secara mudah dan sederhana oleh masyarakat terutama di pedesaan. Pembiasaan terhadap usaha diversifikasi bahan pangan ini, disamping akan menjamin ketahanan pangan masyarakat, juga akan mendukung mobilisasi ekonomi masyarakat. Desa Kasean merupakan daerah di Kecamatan Manding yang berpotensi sebagai penghasil garut di Kecamatan Sumenep. Berdasarkan Data Kecamatan Manding dalam Angka 2018 yang dikeluarkan oleh BPS (2018), Desa Kasengan merupakan daratan tinggi/pegunungan yang digunakan untuk budidaya umbi garut. Tanaman garut telah dibudidayakan di daerah Jawa Tengah dan Jawa Timur dengan produktivitas $2 \mathrm{Kg} / \mathrm{m} 2$ (Faridah, Fardiaz, Andarwulan, \& Sunarti, 2014).

Pada kenyataannya, di pedesaan umbi garut hanya dimanfaatkan sebgai sumber makanan pokok dan pakan ternak. Tujuan untuk mengolah umbi garut menjadi produk olahan pangan yang bernilai nutrisi dan ekonomis tinggi belum tercapai. Kesadaran untuk kemandirian pangan perlu diberikan kepada masyarakat, mengingat untuk mencapai kesejahteraannya, maka masyarakat jugalah yang dapat menggerakkan dan mengembangkan bahwa ada alternatif bahan pangan yang mudah dibudidayakan dan bernilai cukup ekonomis untuk meningkatkan pendapatannya (Sukesi, 2010). Untuk itu perlu segera dilakukan pelatihan dan pendampingan untuk masyarakat dalam pengolahan produk pangan berbahan dasar garut melalui kegiatan pemberdayaan masyarakat atau pengabdian kepada masyarakat ini agar tercipta suatu kondisi kemandirian pangan sekaligus menjaga ketahanan pangan lokal serta memperbaiki mekanisme perekonomian rakyat. Permasalahan mitra yang ingin diselesaikan dalam kegiatan pengabdian ini adalah 1) belum optimalnya penanganan lepas panen umbi garut, spesifik pada pengolahan umbi garut (tepung) menjadi berbagai produk olahan pangan; 2) terbatasnya info dan fasilitas terkait pengolahan umbi garut menjadi produk olahan pangan. 


\section{METODE PELAKSANAAN}

\section{Lokasi dan Waktu Pelaksanaan}

Lokasi pelaksanaan kegiatan persiapan, pelatihan, dan pendampingan pengolahan pasca panen umbi garut (pati umbi garut) yaitu di Laboratorium Pengolahan Pangan, THP dan di Balai Desa Kasengan, Kec. Manding, Kabupaten Sumenep. Waktu pelaksanaan Pengabdian kepada Masyarakat berlangsung dari bulan Mei hingga Nopember 2019.

\section{Kelompok Sasaran}

Kelompok sasaran dalam kegiatan Pengabdian kepada Masyarakat Umbi Garut adalah Kelompok Tani Lokasi pelaksanaan kegiatan persiapan, pelatihan, dan pendampingan pengolahan pasca panen umbi garut (pati umbi garut) yaitu di Laboratorium Pengolahan Pangan, THP dan di Balai Desa Kasengan, Kec. Manding, Kabupaten Sumenep. Waktu pelaksanaan Pengabdian kepada Masyarakat berlangsung dari bulan Agustus hingga Oktober 2019.

\section{Tahapan Kegiatan}

Pelaksanaan kegiatan Pengabdian kepada Masyarakat (PKM) tentang pengolahan pasca panen umbi garut ini dilakukan dengan dua metode pendekatan yaitu pelatihan dan pendampingan. Pendekatan pelatihan yaitu Pelatihan teknologi pengolahan pasca panen umbi garut, sedangkan metode pendampingan yaitu 1) Pendampingan keterampilan teknologi pengolahan umbi garut untuk menghasilkan produk olahan umbi garut, 2) pendampingan teknologi pengemasan produk olahan umbi garut.

Rangkaian kegiatan dalam Pengabdian Kepada Masyarakat (PKM) sebagai berikut:

1. Koordinasi dengan Mitra (Kelompok Tani Pelangi)

Koordinasi dilakukan setelah adanya kepastian dari LPPM Universitas Wiraraja tentang kegiatan ini dan dimaksudkan untuk melihat kesiapan lokasi dan sasaran atau mitra sebagai potret awal daerah kegiatan.

2. Penyusunan modul pelatihan pengolahan produk olahan tepung umbi garut

3. Penyiapan sarana dan prasarana

Sarana dan prasarana yang pelu dipersiapkan pada kegiatan ini meliputi; (1) alat dan bahan pelatihan; (2) tepung umbi garut. Kegiatan ini dibantu oleh mahasiswa Prodi Teknologi Hasil Pertanian.

4. Pelaksanaan pelatihan

Pada tahap ini mitra akan dilatih untuk mengenal teknologi proses pasca panen umbi garut, mulai dari teknik penyiapan bahan dan alat, proses panen, teknik pencucian, dan teknik penepungan, dan teknik pengolahan produk pangan umbi garut. Peserta yang terlibat pada kegiatan ini adalah Kelompok Tani Pelangi di Desa Kasengan Kecamatan Manding.

5. Pemantauan dan refleksi

Pada saat kegiatan berlangsung, setiap tahapan proses akan dilakukan pemantauan dan dicermati/dikendalikan, sesuai dengan rencana dan tujuan yang telah ditetapkan. Bila terjadi suatu keadaan yang di luar perhitungan, maka akan segera dilakukan langkah penyesuaian dan tindakan perbaikan. 


\section{Evaluasi Kegiatan}

\section{HASIL DAN PEMBAHASAN}

\section{Koordinasi dengan Mitra (Kelompok Tani Pelangi)}

Kegiatan ini bertujuan untuk melihat kesiapan lokasi dan sasaran atau mitra sebagai potret awal daerah kegiatan. Hal yang pertama dilakukan adalah menghubungi perwakilan penyuluh pertanian di Desa Kasengan yaitu Ibu Khairun Nisak yang membantu tim dalam memetakan permasalahan yang ada di kelompok tani Pelangi

\section{Penyusunan modul pelatihan pengolahan produk olahan pati Umbi Garut}

Modul pelatihan pengolahan produk olahan pati umbi garut disusun oleh tim yang terdiri dari R. Amilia Destryana (Pengajar di Prodi THP Universitas Wiraraja) dan Ika Fatmawati P., (Pengajar di Prodi Agribisnis Universitas Wiraraja). Modul pelatihan ini disusun dalam rangka membantu pelaksanaan ceramah atau penyuluhan yang dilakukan pada saat tahap sosialisasi dan tahap pelatihan. Pada tahap sosialisasi materi ceramah yang diberikan adalah tentang diversifikasi produk olahan berbahan dasar komoditas lokal, di antaranya kelor, jahe, jagung, garut dan rumput laut. Pada tahap pelatihan, ada dua tahapan materi yang disampaikan yaitu materi tahap 1, yaitu Teknologi Pengolahan Pangan Komoditas Pati Umbi Garut dan prinsip-prinsipnya, sedangkan materi tahap 2 adalah berbagai macam kegiatan pasca produksi yaitu pengemasan, pelabelan, perijinan produk untuk dipasarkan dan aspek manajemen usaha.

\section{Penyiapan Sarana dan Prasarana}

Kegiatan ini berlangsung di Lab. Teknologi Pengolahan Pangan, Prodi THP. Bahan utama yang pelu dipersiapkan pada kegiatan ini adalah pati umbi garut. Pati umbi garut diproduksi berdasarkan penelitian (Faridah et al., 2014). Terbatasnya komoditas umbi garut yang diperoleh di pasar, jumlah pati garut yang kami peroleh tidak dapat memenuhi jumlah produk olahan yang dibuat, dengan pertimbangan pengoalahan kue kering yang relatif mudah, maka produk olahan yang kami demonstrasikan kepada kelompok aalah satu produk olahan saja, yaitu produk kue kering pati garut. Selain bahan utama, sarana dan prasarana yang kami siapkan meliputi (1) alat dan bahan tambahan lainnya dalam pelatihan. Mahasiswa Prodi THP membantu dalam persiapan produksi pati garut dan persiapan pembuatan kue kering pati garut.

\section{Pelaksanaan Pelatihan}

Kegiatan yang pertama dilakukan adalah penyampaian materi Teknologi Pengolahan Pangan Komoditas Pati Umbi Garut dan prinsip-prinsipnya, kemudian dilanjutkan penyampaian materi tahap 2 yaitu Berbagai macam kegiatan pasca produksi yaitu pengemasan, pelabelan, perijinan produk untuk dipasarkan dan aspek manajemen usaha, jadwal kegiatan terlihat pada Tabel 1. Pada sesi kegiatan ini dilakukan kegiatan diskusi antara pemateri dan kelompok tani (Gambar 1 dan Gambar 4).

Tabel 1. Jadwal Pelatihan Pengolahan Pasca Panen Umbi Garut pada 22 Oktober 2019

\begin{tabular}{|c|l|}
\hline JAM & \multicolumn{1}{|c|}{ ACARA } \\
\hline $08.00-08.30$ & Persiapan dan Registrasi Peserta \\
\hline $08.31-08.45$ & Pembukaan dan Doa \\
\hline
\end{tabular}




\begin{tabular}{|c|c|}
\hline $08.45-09.30$ & $\begin{array}{ll}\text { - } & \text { Sambutan dari PPL Desa Kasengan } \\
\text { - } & \text { Sambutan dari Ketua Tim PKM } \\
\end{array}$ \\
\hline $09.30-12.00$ & $\begin{array}{l}\text { Pelatihan dan Diskusi } \\
\text { Materi } 1 \text { : oleh R. Amilia Destryana, MP., M.Sc } \\
\text { Teknologi Pengolahan Pangan Komoditas Pati Umbi Garut } \\
\text { dan prinsip-prinsipnya. Pelatihan Pembuatan Kue Kering } \\
\text { Garut }\end{array}$ \\
\hline $13.00-14.00$ & $\begin{array}{l}\text { Materi } 2 \text { : oleh Eko Adi Sumitro, M.Pd } \\
\text { Berbagai macam kegiatan pasca produksi yaitu } \\
\text { pengemasan, pelabelan. } \\
\text { Materi } 2 \text { : oleh Aryo Wibisono, ST., MM } \\
\text { Berbagai macam kegiatan pasca produksi perijinan produk } \\
\text { untuk dipasarkan dan aspek manajemen usaha }\end{array}$ \\
\hline $14.00-15.00$ & Diskusi bersama \\
\hline $15.00-15.30$ & Penutup \\
\hline
\end{tabular}

Demonstrasi adalah metode penyuluhan yang digunakan dalam kegiatan PKM ini, dengan tujuan untuk pendekatan kelompok untuk dapat diajak kerja sama, dimbimbing dan diarahakan secara berkelompok untuk melakukan suatu kegiatan yang lebih produktif (Meiyasa, Tarigan, Efruan, Sitaniapessy, \& Pati, 2019). Dalam kegiatan PKM ini, demonstrasi yang dilakukan dengan dua acara yaitu, demontrasi cara pengolahan kue kering pati garut (Gambar 2) dan demontrasi hasil menghias kue kering pati garut hasil panggangan. Tujuan dari kegiatan ini adalah memberi gambaran pada peserta mengenai cara kerja proses pengolahan kue kering pati garut dan olahan lainnya. Demontrasi yang kedua bertujuan untuk menunjukkan secara nyata dari hasil proses pengolahan kue kering pati garut (Gambar 3).

Pada kegiatan ini, peserta dilatih untuk mengetahui formulasi yang tepat dan teknik pembuatan pati garut, kue kering dan produk olahan lainnya berbahan dasar pati garut baik ditinjau dari rasa, warna, tekstur, dan penampakan dari produk tersebut, serta kemasan yang dapat diterima oleh konsumen.

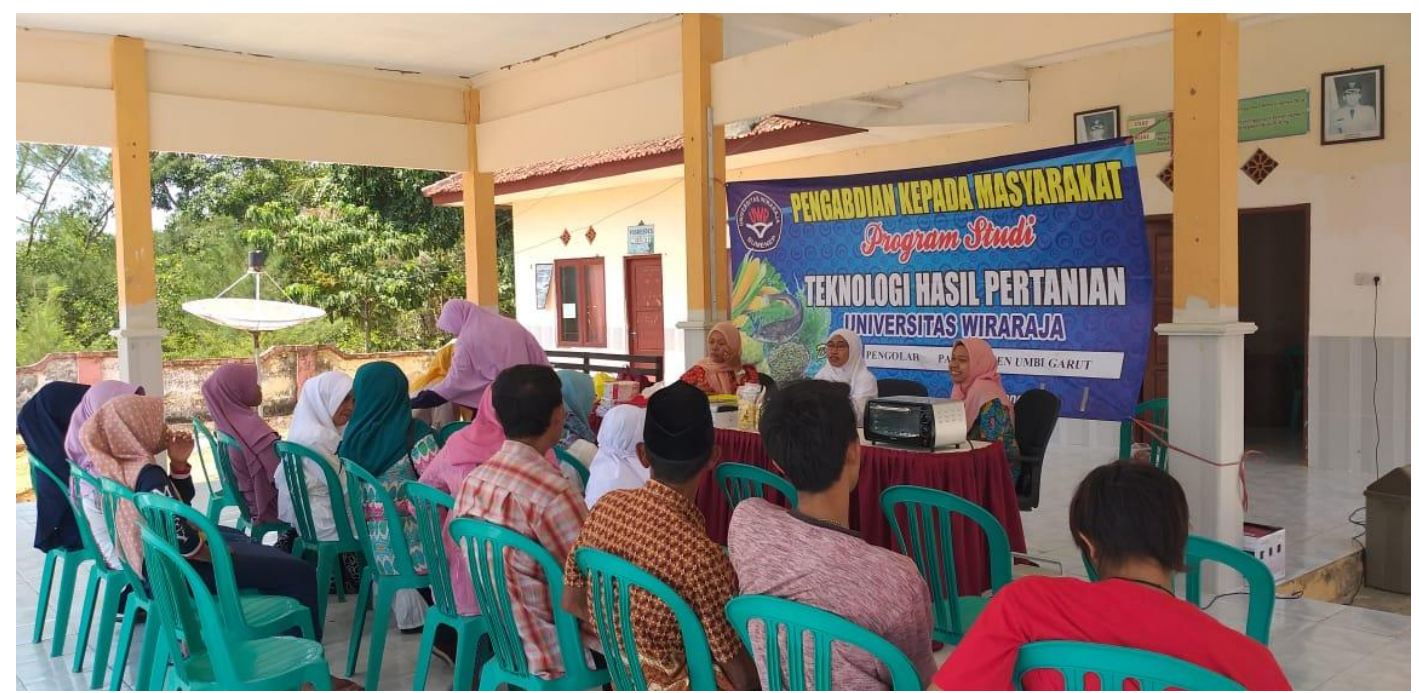

Gambar 1. Penyampaian materi Pelatihan Pengolahan Pasca Panen Umbi Garut 


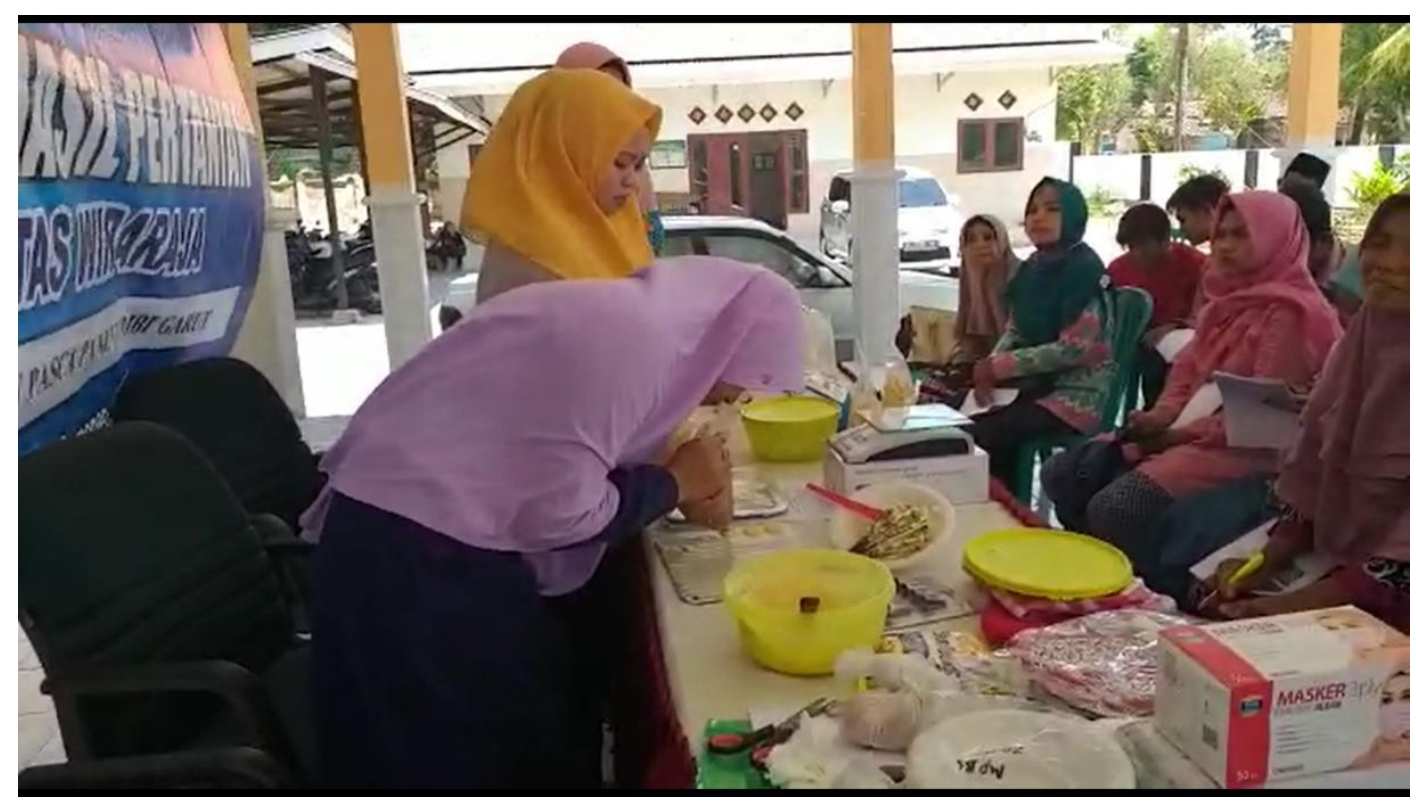

Gambar 2. Demontrasi Pembuatan Kue Kering Pati Garut

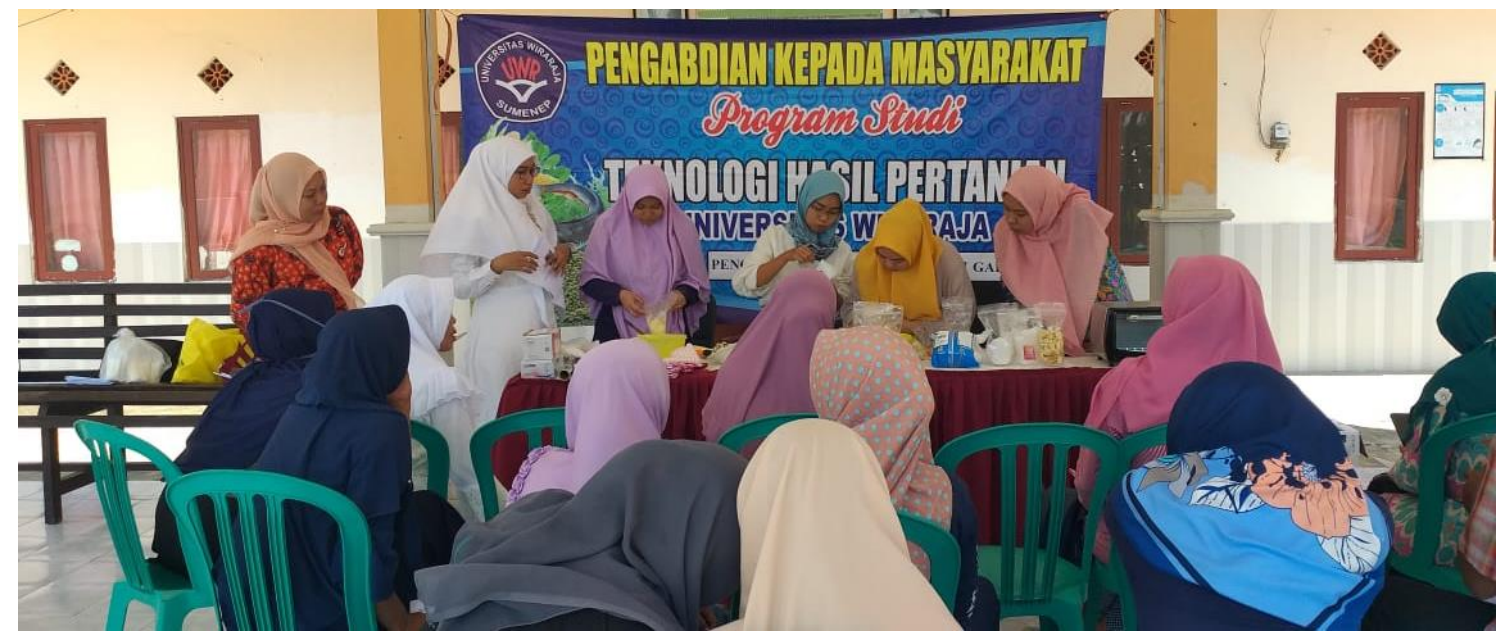

Gambar 3. Praktik Peserta dalam Pembuatan Kue Kering Pati Garut

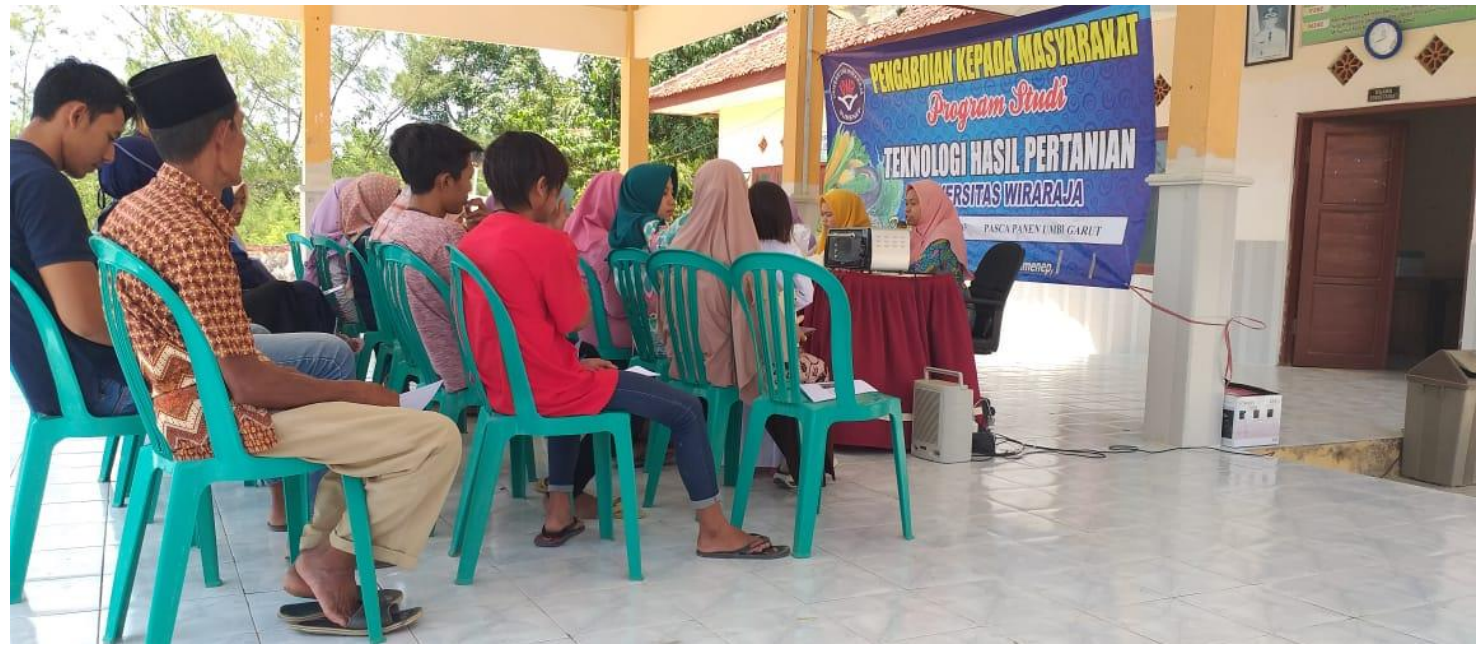

Gambar 4. Sesi diskusi dan tanya jawab 


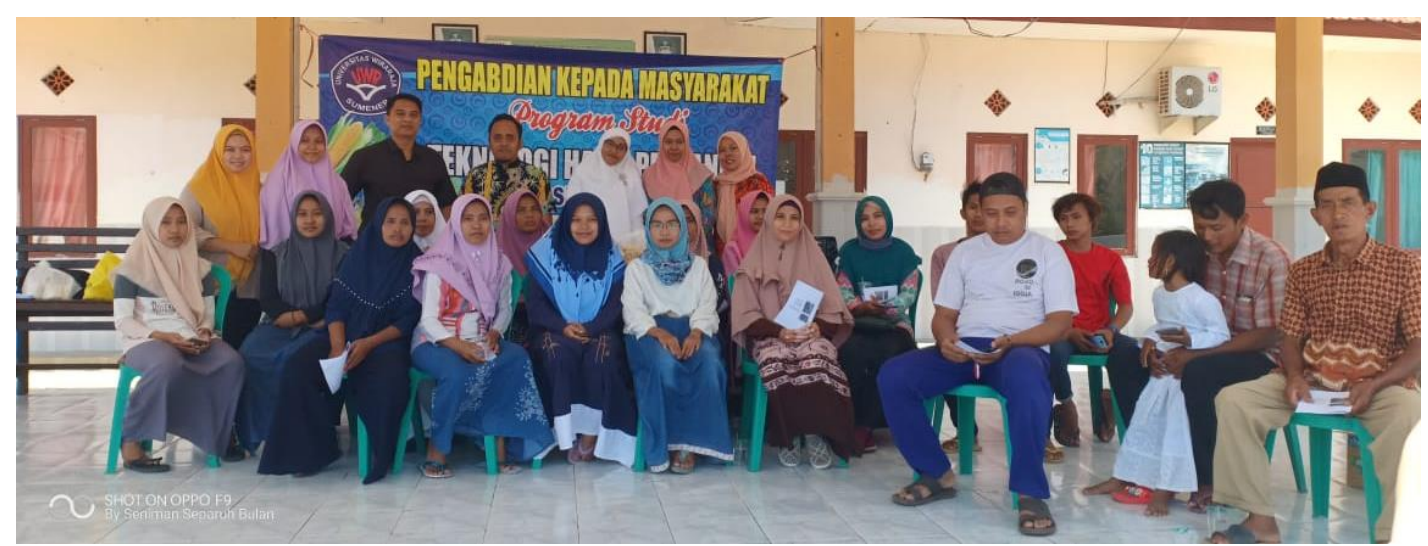

Gambar 5. Foto Bersama Tim PKM dan Kelompok Tani Pelangi dan KWT Putri Keramat

\section{Pemanfaatan dan Evaluasi}

Kegiatan pendampingan dan pemasaran dilakukan setelah kegiatan pelatihan dan praktik pembuatan kue kering. Pendampingan ini dilakukan 2 kali selama kegiatan pengabdian berlangsung. Dalam tahap kegiatan ini dilakukan pendampingan di kelompok tani Pelangi. Pada setiap kelompok masih tetap dilakukan pendampingan dalam proses pembuatan pati garut dan kue kering. Tujuan dari kegiatan pendampingan ini adalah untuk memaksimalkan pengetahuan dan praktik yang dilakukan oleh kelompok. Kegiatan ini juga dilakukan untuk menjaga konsistensi produk dari segi warna, rasa, tekstur, dan penampakan produk (Soetignya, Laksana, \& Munir, 2018). Hasil dari setiap pendampingan, produk yang dihasilkan kemudian dipasarkan. Target pemasaran produk ini adalah di by order, swalayan, toko/ outlet yang ada di Kota Sumenep. Hasil dari kegiatan evaluasi, jumlah panen umbi garut yang tidak menentu masih menjadi hambatan keberlangsungan produksi pati garut.

\section{SIMPULAN}

Beberapa kesimpulan yang dapat diambil dari kegiatan PKM ini adalah 1) Respon positif dari kelompok dalam bentuk keaktifan dan peningkatan keterampilan kelompok tani Pelangi terkait penanganan lepas panen umbi garut, spesifik pada pengolahan umbi garut (tepung) menjadi berbagai produk olahan pangan. Selain itu, Mitra PKM dapat mengaplikasikan proses pengolahan produk olahan pati garut dengan mudah.

Rekomendasi untuk kegiatan pengabdian kepada masyarakat berikutnya adalah pemanfaatan komoditas lokal lainnya di Desa Kasengan yang berpotensi dalam produksi olahan pangan fungsional. Selain itu, perlunya jejaring pemasaran yang lebih luas daripada pasar lokal.

\section{DAFTAR PUSTAKA}

Djaafar, T. F., \& Pustika, A. B. (2016). Pengembangan Budi Daya Tanaman Garut dan Teknologi Pengolahannya Untuk Mendukung Ketahanan Pangan. Jurnal Penelitian Dan Pengembangan Pertanian, 29(1).

Faridah, D. N., Fardiaz, D., Andarwulan, N., \& Sunarti, T. C. (2014). Karakteristik sifat fisikokimia pati garut (Maranta arundinaceae). Agritech, 34(1), 14-21. 
Hasan, V., Astuti, S., \& Susilawati, S. (2012). Indeks Glikemik Oyek Dan Tiwul Dari Umbi Garut (Marantha arundinaceae 1.), Suweg (Amorphallus campanullatus BI) dan Singkong (Manihot utillisima). Jurnal Teknologi \& Industri Hasil Pertanian, 16(1), 34-50.

Meiyasa, F., Tarigan, N., Efruan, G. K., Pati, D. U., \& Sitaniapessy, D. A. (2019). Pelatihan Pembuatan Stik dan Pilus Rumput Laut pada Kelompok Usaha Kelurahan Kambajawa. Jurnal PkM Pengabdian kepada Masyarakat, 2(03), 212220. http://dx.doi.org/10.30998/jurnalpkm.v2i03.3525

Soetignya, W. P., Laksana, W., \& Munir, A. M. S. (2018). Peningkatan Pendapatan Masyarakat Desa Beginjan, Kabupaten Sanggau Melalui Pengolahan Produk Ikan Asli Kalimantan. Jurnal PkM Pengabdian Kepada Masyarakat, 1(03), 296. https://doi.org/10.30998/jurnalpkm.v1i03.2750

Sukesi, H. (2010). kajian rantai Pasokan dan PenganekaragaMan konsuMsi Pangan berbasis Produk uMbi-uMbian: studi kasus jaWa barat. Buletin Ilmiah Litbang Perdagangan, 4(1), 31-62. https://doi.org/10.30908/bilp.v4i1.145 